\title{
PLANT VIRUS ECOLOGY: A GLIMPSE OF RECENT ACCOMPLISHMENTS
}

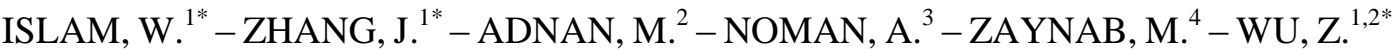 \\ ${ }^{I}$ Fujian Province Key Laboratory of Plant Virology, Institute of Plant Virology, Fujian \\ Agriculture and Forestry University, Fuzhou, Fujian 350002, China \\ ${ }^{2}$ College of Plant Protection, Fujian Agriculture and Forestry University, Fuzhou, \\ Fujian 350002, China \\ ${ }^{3}$ College of Crop Science. Fujian Agriculture and Forestry University, Fuzhou, \\ Fujian 350002, China \\ ${ }^{4}$ College of Life Science. Fujian Agriculture and Forestry University, Fuzhou, \\ Fujian 350002, China \\ *Corresponding author \\ e-mail:wuzujain@126.com; Jiezhang@163.com;ddoapsial@yahoo.com \\ (Received 20 $0^{\text {th }}$ Sep 2016; accepted $1^{\text {st }}$ Dec 2016)
}

\begin{abstract}
Plant virus ecology mainly focuses upon populations and their interactions with host plants within environment. The subject includes interesting insights as many factors which affect the virus behavior, population, virus-vector interactions, biodiversity and host plants genotypes are involved in it. Moreover the achievements in the field of molecular ecology by application of recent molecular biology techniques are included which enhance the strength in understanding the economically important virus populations, growth and their world wide spread. Virus infection results direct and indirect effect on insect vectors by evolution of changes in their life cycles, health and interacting behaviors that support their spread. Similarly, the description of the recent information about how plant viruses disseminate towards the important agro-ecological zones in naturally managed vegetations and which factors play important role in ecological aspects are also included in this review. The modern era of science and technology requires a better understanding about movement of viruses in both directions which has become a highly important issue to levitate such kinds of aspects thus making plant virus ecology an exciting research discipline in future.
\end{abstract}

Keywords: biodiversity, insect vector, ecosystems, ecological factors, molecular

\section{Introduction}

Plant virus ecology is an indispensible discipline, focusing upon the viruses populations within a particular environment. This discipline further targets the complicated associations as well as interactions between the viruses and the hosts causing the economically important disease spread (Wilson, 2014). Ecology of viruses can be taken as the study of different factors which influence or affect the behavior of a virus under specific environmental conditions (Hull, 2002). It is also considered as a study of virus behavior in its ecosystem and the factors affecting its population (Wilson, 2014). During the earlier decades of last century, plant virus ecology looked disconnected with the basic discipline of plant ecology due to differentiation between plant ecology and plant virology. The least availability of viral symptoms on less economically important plants (Cooper and Jones, 2006; Jones, 2014b; Malmstrom et al., 2011; Prendeville et al., 2012; Roossinck, 2013) resulted in reduction of covering the important aspects in this research field. In recent literature, the plant virus ecology is 
described with spread of viruses in commonly cultivated crops and weeds (Thresh, 2003, 2006a,b,c; Jones, 2004, 2014b; Gallitelli, 2000; Thresh and Fargette, 2003; Morales and Jones, 2004; Coutts et al., 2008; Makkouk and Kumari, 2009; Traore et al., 2009; Adkins et al., 2011; Culbreath and Srinivasan, 2011; Olarte-Castillo et al., 2011; Hull, 2014). Plant virus ecology gives an insight of a complex of virus-hostenvironment correlation and interactions. This field includes the aspects of plant virus biodiversity, including sampling against the viruses from infected plants directly and from other ecosystems; how plant viruses invades the emerging and invasive species; interactions between plants communities involving mixed and wild plant populations, insects and insect vectors ; persistent viruses showing epigenetic effects; soil born plant viruses and their surrounding soil ecosystems; molecular basis of viral genomics ; ecological factors impacting upon plant viruses and modern technological innovations helping in research about the viruses. This review includes the important aspects on the plant virus ecology in modern era and concludes by understating the rapid advancement and innovation in the technology.

\section{Plant Virus Biodiversity}

History reveals that most of the research findings were done accidently while studying some other aspects. For example, Tobacco mosaic virus was found accidently while searching for the disease causing agent of a tobacco disease (Beijerinck, 1898). However, due to technological innovations, viruses infection to the non-crop hosts is being studied, leading to the contradictory results against the opinion of the most plant scientists illustrating our knowledge about the plant viruses is still very little (Roossinck, 2012a). Result oriented approach is being followed to study biodiversity, where samples of different environments are analyzed against particular virus sequence after enrichment for viruses but plant virologists adopted another way by individual plants sampling (Roossinck et al., 2010). In this way, each sequence can be tracked towards its specific host thus allowing deeper ecological and evolutionary analyses (Roossinck, 2012a). The data from recent sequencing of samples from marine samples supports that around 2,000 viral species may exist on our planet (Breitbart and Rohwer, 2005). Regarding viral diversity, a little data is available about mixed virus infections or temporal viral infections in native plants. So it is really important to attain more and more knowledge about viruses, their hosts and existing host and virus combinations causing disease to next level that can be very damaging in future (Jonathan et al., 2012). In this regard, the plant virus biodiversity and ecology project played an important role in conducting the vascular plants survey in the nature conservancy's tall grass prairie preserve of Oklahoma, the reservoir of over 700 plant species. Most of the plant species in Costa Recon region showed positive response towards double-stranded RNA viruses. These show that there is a huge difference in our understanding regarding ecology, evolution and viral diversity.

\section{Emerging Plant Viruses}

International Committee for Taxonomy of Viruses (ICTV) has enlisted approximately 900 species of plant viruses (King et al., 2012). Several metagenomic studies have identified viruses resembling to plant viruses in a wide range of sample (Human and other mammals feces; fresh, marine, reclaimed water; soils from paddy 
fields and plant-feeding insects). All of these viruses from previously mentioned samples are from a particular genera having exclusively stable capsid, e.g. Tobamo viruses. A prevalent example is Pepper mild mottle virus found in waste water (Rosario et al., 2009). Reviewing the emerging plant pathogens, studies show that $50 \%$ of the newly emerging viruses belong to a category of DNA or RNA viruses (Anderson et al., 2004). RNA viruses perform host shifting mechanism easily than others (Longdon et al., 2014). Viruses show evolution of changes before invading new plant species, guaranteeing their survival within their new hosts (Longdon et al., 2014; Roossinck et al., 2015). Varma and Malathi (2003) emphasized upon the fast emergence of geminiviruses and explained that they were the most important crop pathogens. Boulton (2003) referred that the disease outbreaks were due to evolutionary changes in the begomoviruses and their dissemination abilities. The emergence of geminivuses in tropics and subtropics was documented in a number of publications. Examples are infection of begomoviruses to: tomato and pepper in North Africa (Tahiri et al., 2006), south-east Asia (Tsai et al., 2011), South America (Martínez-Ayala et al., 2014); legume crops in south-east Asia (Tsai et al., 2011, 2013) and in South America (RodríguezPardina et al., 2011; Martínez-Ayala et al., 2014) and cassava crops in sub-Saharan Africa (Ssweruwagi et al., 2004). In Taiwan, Cheng et al. (2014) observed the infection of this particular virus shown mottling symptoms in fruit and leaf as well as deformation in pepper and given this a provisional name Pepper chlorotic spot virus (Fig. 1). So, new viruses are spreading towards the new plant hosts under the umbrella of natural ecosystems thus threatening the plant biodiversity (Jones and Coutts, 2015).

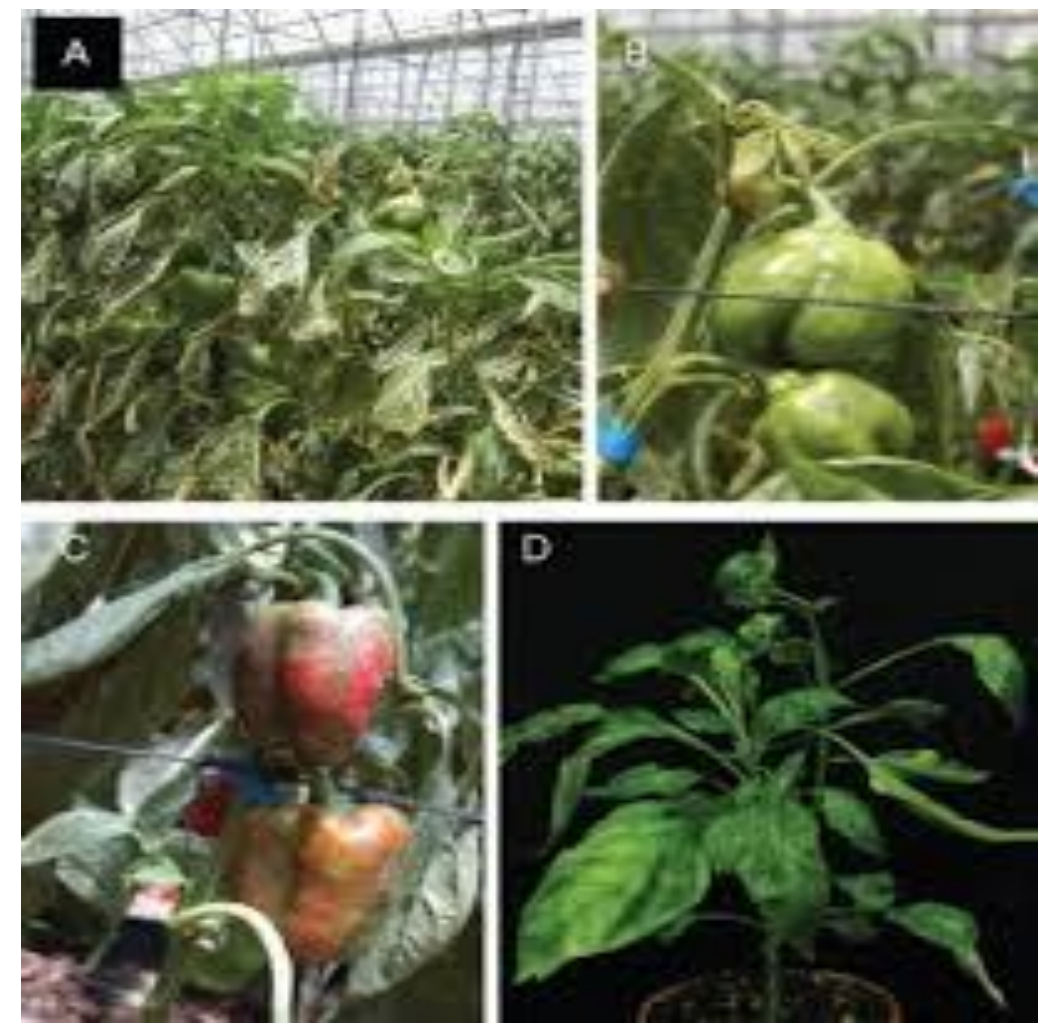

Figure 1. (A) Pepper chlorotic spot virus (PCSV-TwPep3) symptoms on sweet pepper observed under field conditions; (B) Bud necrosis; (C) Fruit mottle; (D) In vivo leaf mottle and bud necrosis. Source: Cheng et al., 2014 


\section{Insect Vector Ecology}

Recent studies illustrate that viruses can turn plants more attractive for the insects by impounding some changes in volatile compounds produced by the plants. This may lead to the theory that insects feed more at infected plants (Mauck et al., 2012). Further studies describes that plant infected by persistent viruses are more attractive than infected by non persistent ones (Mauck et al., 2012). The transmission of plant viruses can be carried out by insects in two principal methods; one is circulative pathway which includes circulation of viruses through the haemocoel of the insect and the other is non circulative which only involves the foregut or mouth parts of the insect (Fereres and Raccah, 2015).

Viruses can reflect changes in host plants behavior towards the insects. Examples include the transmission of persistent viruses by aphids in wheat (Barley yellow dwarf virus) and potato (Potato leaf roll virus) (Bosque-Pérez and Eigenbrode, 2011). Similarly, it was found that when the insect vector feeds on the infected plant and get virus acquisition, its feeding behavior changed directly afterwards (Stafford et al., 2011; Ingwell et al., 2012; Shestra et al., 2012; Moreno-Delafuente et al., 2013; Rajabascar et al., 2014; Carmo-Sousa et al., 2014). Regarding indirect modifications that include the alterations in the vector (white fly) behavior or its performance after landing and feeding on infected plants is documented (Jiu et al., 2007; Wang et al., 2012; Zhang et al., 2012). Sometimes, the changes inserted in the host plants by the viruses lead towards the changes in virus vector interactions, transmission towards new hosts e.g. (Cilia et al., 2012; Westwood et al., 2013; Zhou, 2013). For example, the increased settling of viral proteins inside the aphid reduces the Cocumber mosaic virus (CMV) transmission while discouraging settling would enhance CMV transmission to healthy plants (Westwood et al., 2013).

Viruses can lead towards the modifications of insect vector life cycles, fitness and behavior directly or indirectly. Direct changes occur when the virus remain inside the insect for its whole life span. For example, in tomato TYLCV (Tomato yellow leaf curl virus) remained in the body of white fly thus influencing vector settling, probing and feeding (Moreno-Delafuente et al., 2013). Further research revealed that the interaction between virus and vector was mutually beneficial for each other specifically for the biotype Q only (Pan et al., 2013). Similarly in thrips interaction, the feeding behavior of male Frankliniella occidentalis (Pergande, 1985) infected by TSWV (Tomato spotted wilt virus) was changed thus influencing the transmission of the virus (Stafford et al., 2011). Natural enemies of insect vectors also play an important role in altering virus spread patterns by using different strategic methods. According to Dáder et al. (2012) Aphid parasitoid, Aphidius colemani Viereck 1912 increased the spread of nonpersistently transmitted CMV in cucumber, but reduced the spread of persistently transmitted Cucurbit aphid-borne yellows virus.

\section{Molecular Ecology}

As the genome of plant virus is simple, it makes it ideal subject for molecular ecology studies. Molecular ecology research shows that the genomic sequence of viruses acquire signatures which describe their histories that help in understanding the ecological patterns and evolutionary processes. These patterns can be understood if natural host range is known (Traore et al., 2009). The ecological patterns and virusplant interaction systems were described previously as well in which improvements in 
virus population traceability, epidemic disease appearance patterns and testing the durability of virus or vector selective control measures were included. e.g. (Fargette et al., 2006; Gibbs et al., 2008; Desbiez et al., 2009; Traore et al., 2009; Lecoq et al., 2011; Olarte-Castillo et al., 2011; Acosta-Leal et al., 2011; Malmstrom et al., 2011; Thapa et al., 2012; Roossinck, 2012 b; Rodelo-Urego et al., 2013; Jones, 2014b) .Garcia -Arenal in his project of plant virus interactions and co-evaluations focused upon a two-host evaluation systems model for cucumbers mosaic virus showing plants Infection possibilities by virus genotypes $\mathrm{Y}, \mathrm{A}$ and $\mathrm{N}$ competing in mixed infections (M). Genetic diversity shown how basic information from different field experiments lead to the use of molecular diagnostic tools to study the virus populations and their influences on different crops (Pagan et al., 2012). A bright future of plant virus ecology is ahead because the combination of molecular and traditional approaches in the discipline are being brought together to collect the details of virus genetic variations and epidemic breakouts which were impossible in the previous years (Jones, 2014a).

\section{Factors Affecting Plant Virus Ecology}

Viruses cause diseases in most plants due to the interactions of susceptible host, virulent pathogen and a suitable environment. Similarly biotic and abiotic stresses post a huge impact upon the crop health and yield (Ludmerszki et al., 2014; Noman et al., 2015). The interaction of all these factors and many more other factors shows a complex connection. These may include climate changes (temperature, wind speed, light duration, rainfall), insect vector movement pattern, feeding behavior, population of host plant their genotypes, weeds, human activity, mixed plant populations, wild plant communities, invasive plant species and impacts of worldwide trade. The disease triangle illustrates the importance of all the interactions required for disease development (Jones and Barbetti, 2012) (Fig. 2).

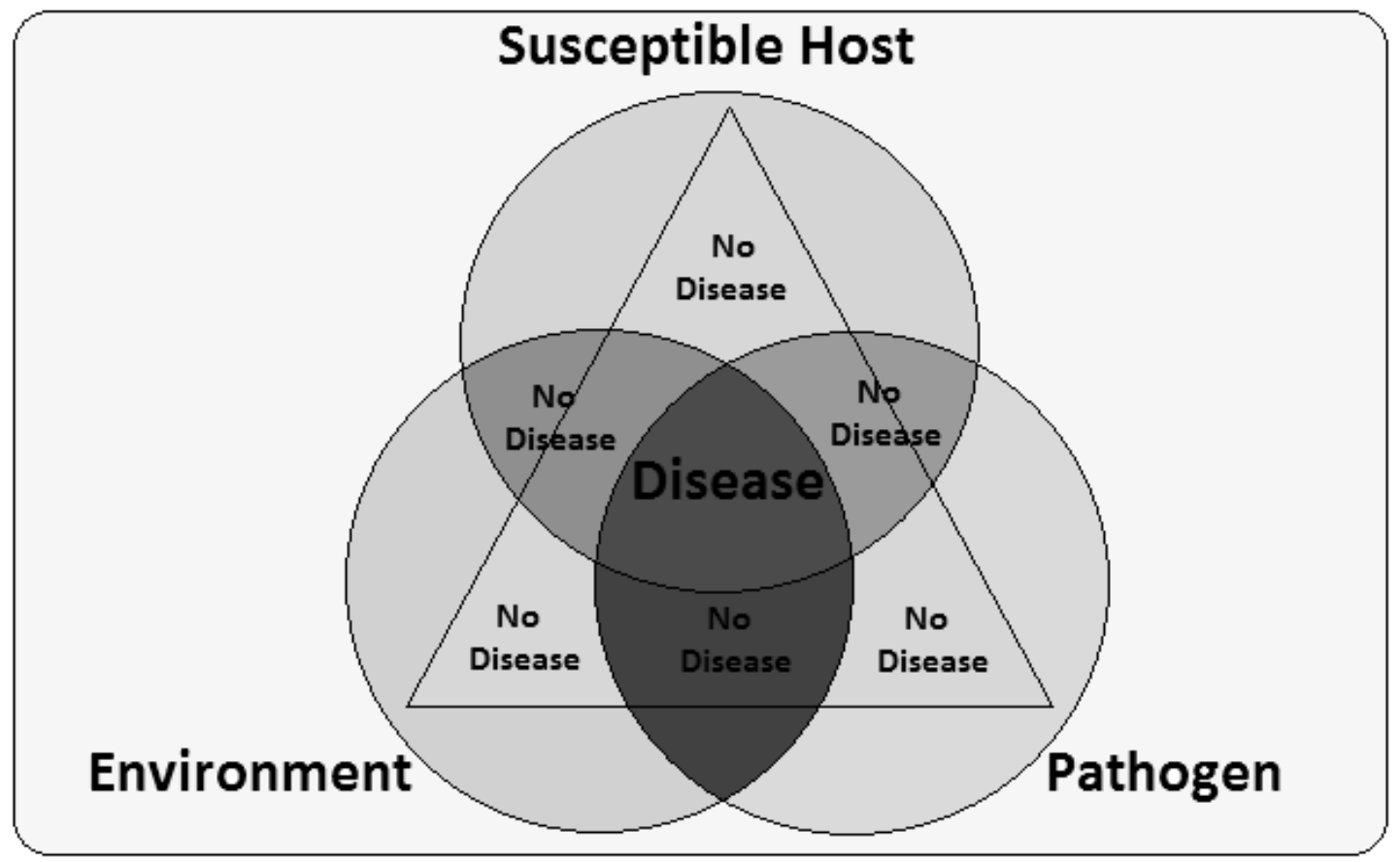

Figure 2. Plant Disease Triangle 


\section{Climate Change}

According to NASA Earth Observatory, in $21^{\text {st }}$ century the global temperature will rise by $2-6^{\circ} \mathrm{C}$ which will lead to the devastating changes for ecology of plant viruses. For example, the population of whitefly starts building up in high temperature and high relative humidity levels and shows were declining at low temperature and high rainfalls. Temperature also effects virus proliferation by causing changes in gene silencing (Chellappan et al., 2005; Vanitharani et al., 2005). Furthermore, light and humidity also manipulates viral symptoms through induced gene silencing ( $\mathrm{Fu}$ et al., 2006). Extreme weather events that include adverse rains, wind storms, heat wave patterns and drought spans are predictable due to better technology now a day. Such events divide the world in different ecological sensitive zones (Fig. 3). However, capability of plants as well as viruses in adaptation to extreme weather patterns is great, such as adoptability of plants in geothermal soils of Yellowstone National Park against fungal endophytes infected by viruses (Márquez et al., 2007). The extraordinary changes in ecosystem can significantly bring changes in the range of cultivated plants and their cultivated area, resulting in the introduction of new weeds, and increased activity of insect vectors thus promoting the disease spread (Harrington et al., 2001).

\section{$21^{\text {st }}$ Century Ecological Sensitivity}

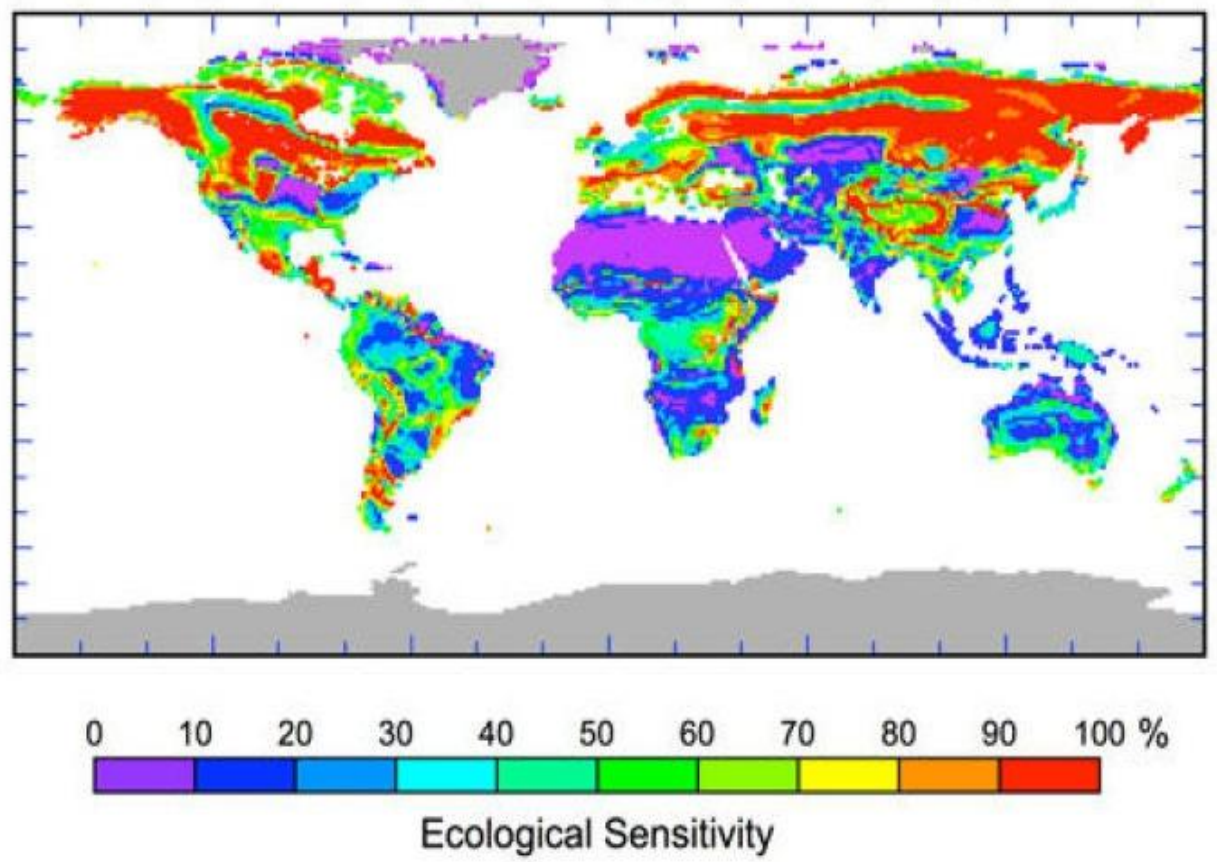

Figure 3. 21st Century Ecological Sensitivity - Changes in Plant Species (John, 2011)

Tropical cyclones in the future are expected to become more extreme. Storms are projected to move pole wards in future, with consistent changes in winds, precipitation and temperature patterns (Metz et al., 2007; Parry et al., 2007). These insecure weather patterns test human ability to manage plant virus diseases effectively (Jones and Barbetti, 2012). 


\section{Movement and Feeding Behavior of Insect Vector}

The spread of any disease in time and space is dependent upon the positive correlation of insect vector movement to population size. The vectors movement involves some steps for appropriate landing upon the host and then starts its feeding (Fereres and Moreno, 2009). Moreover plant virus transmission is specific by the help of certain insects and their transmission modes, persistence and localizations can be varied accordingly by Insect vector which is explained in Table 1. Some studies reveal that plant viruses can modify insect behavior directly. For example, viruliferous aphids by BYDV were attracted to uninfected host plants, whereas non viruliferous aphids were attracted to infected plants (Ingwell et al., 2012). Carmo-Sousa (2014) explained that when the vector came in contact to the CMV infected plants, a change in the probing and settling behavior of Aphids was initiated and increased by the time. The plants infected by $\mathrm{CV}$ viruses excrete some volatile compounds that increased the attraction of aphids towards them (Eigenbrode et al., 2002). But the Aphids may feel the plants less attractive for them after they have fed upon them and got virus acquisition (Rajabaskar et al., 2014). Mauck et al. (2015) examined the CMV infected plants of Cucurbita pepo and found that the susceptibility of vector (Aphid) towards its parasitoid (Aphidius colemani) was increased.

Table 1. Different Modes of Virus Transmission

\begin{tabular}{|l|l|l|}
\hline Viruses & Localization & Vector \\
\hline Persistently Transmitted Viruses (Takes Weeks Time) \\
\hline Begomovirus & Salivary gland & Whitefly \\
\hline Curtovirus, Mastreovirus & Unknown & Leafhopper \\
\hline Enamovirus, Luteovirus, Nanovirus & Salivary gland & Aphid \\
\hline Ilarovirus & Unknown & Thrips \\
\hline Semi-Persistently Transmitted Viruses (Takes Few Days Time) & \\
\hline Badnavirus & Unknown & Mealybug, leafhopper \\
\hline Crinivirus & Foregut/Cibarium & Whitefly \\
\hline Closterovirus & Foregut & Aphid, Mealybug \\
\hline Comovirus, Sobemovirus, Tymovirus & Unknown & Beetle \\
\hline Ipomovirus & Unknown & Whitefly \\
\hline Machlomovirus & Unknown & Leafhopper \\
\hline Sequivirus & Foregut & Aphid \\
\hline Torradovirus & Stylet & Whitefly \\
\hline Waikavirus & Foregut & Leafhopper \\
\hline Non Persistently Transmitted Viruses (Takes Few Hours Time) & \\
\hline Alfamovirus, Cucumovirus, Fabavirus, Potyvirus & Stylet & Aphid \\
\hline Carlavirus & Stylet & Aphid or whitefly \\
\hline Caulimovirus & Acrostyle & Aphid \\
\hline Macluravirus & Unknown & Aphid \\
\hline
\end{tabular}

\section{Host Plant Genotype and Populations}

The plant viruses can infect hosts of varying taxonomic status (Woolhouse et al., 2001). For example, the evolution of Pelargonium flower break virus (PFBV) and adaptation to Chenopodium quinoa (Rico et al., 2006). Genetic diversity of virus is 
imposed by its own evolving genomic make up for better sustainability (Schneider and Roossinck, 2001). Frequent availability of host plants leads to disease epidemics. For example, Cotton leaf curl virus (CLCuV) epidemics in Pakistan was resulted due to introduction of new cotton genotypes which proved extremely susceptible towards local virus strains, leading to wiping off cotton crop by CLCuV (Mansoor et al., 2006).

\section{The Role of Weed Plants}

Viruses can infiltrate the annual weeds by passing through seeds and undoubtedly play a vital role in maintaining the population of insect vectors as well in agroecosystems of their cultivated hosts (Norris and Kogan, 2005). The dissemination of several viruses is linked by the movement of insect vector and continuous availability of the host plants. Many weeds are reported as virus hosts of plant viruses by Kucharek and Purcifull (2001). Removal of volunteer plants and weeds from the borders of a particular crop field helps in management of viral diseases by reducing the vector infestation (Momol and Pernezny, 2006). Seasonal changes in the ecosystem are also important in vector dissemination. For example, Bamicia tabaci population exhibit lower levels upon different cultivated and weed plants in winter and spring months. Their migration towards cotton starts in summer leading to the buildup of population. Trebicki (2010) studied some factors that were important in epidemics of Tobacco yellow dwarf virus in Australia and found that the two weed species Amaranthus retroflexus and Raphanus raphanistrum were the virus harbors from which Orosius orientalis (vector) disseminated the virus towards other crops.

\section{Role of Human Beings}

Currently the world is experiencing rapid human activity day by day, resulting in significant impacts upon plants, vectors and viruses leading to un-stability to the virusvector-plant ecosystems (Patel and Fauquet, 2011). The fast and furious human activities include adopting more diverse, expansive and intensive agronomic practices such as: mono or dual cropping systems; enhanced tillage operations; un-judicial chemical usage; raw irrigation methods and similar cropping patterns. All of these help in virus disseminations and epidemic disease break outs (Jones, 2009). Several examples of vast agricultural activities and practices done by human beings inadvertently caused the emergence and epidemics of new diseases (Alexander et al., 2014). Newly introduced vegetations in tropics and sub tropics by humans become more attractive to new virus encounters (Morales and Jones, 2004; Morales, 2006; Jones, 2009; Vincent et al., 2014). Begomoviruses are the best example of adaptations to the new host vegetations (Navas-Castillo et al., 2011). Increasing Human population demands more food which is enhancing the international trade of plant products thus favoring the travelling of viruses. Jones (1980) reported about Pepino mosaic virus movement via trade from Peru. The particular virus infected different Solanaceae species which was proved by the sap inoculation experiments, including potato, tomato etc. Till 2000, the issue remained suppressed but then it appeared in tomato crop in Netherlands and contaminated the seeds (Van der Vlugt et al., 2000). Later on it travelled to European states, northern states of America and China. It further moved to other continents through the activities of international seed companies who sold the infected seeds in the other continents (Mumford and Jones, 2005). 


\section{Wild Plants and Invasive Plant Species}

Preliminary research upon wild plant species describe that hundreds of viruses are needed to be studied and discovered yet (Roossinck et al., 2010, 2012a). In wild Plants, Majority of viruses show persistent life style (Roossinck, 2012b). Maskell et al. (1999) researched upon the virus infection to Brassica oleracea (Wild cabbage) and found that it was vulnerable to the infection of Turnip mosaic virus and a wide range of other viruses. Moreover recently in Nigeria identification of alternative hosts has been done against ACMV (African cassava mosaic virus) and EACMV (East African cassava mosaic virus) species (Alabi et al., 2008). In Uganda, studies have even confirmed about CMV in their wild species such as Manihot glaziovii (Sserubombwe et al., 2008). Moreno et al. (2004) described that in Spain wild plants were the virus harbor, disseminating it to cultivated Lettuce and Brassica. Similarly Sweet potato mild mottle virus about 300 years ago when it entered the Africa, spread from native Convolvulaceae species (Tugume et al., 2013).

Generally invasive species adopt phenomena called pathogen release by which they wash off the pathogens in their surrounding habitat (Mitchell et al., 2003). But in their invasions invasive species can be aided by plant viruses by different mechanisms. For example, they may carry virus's infections apparently that lead to the disease spread in their surroundings or they can show extraordinary tolerance to the viruses existing in that particular environment (Rua et al., 2011). Studies illustrated that population of aphids was increased due to invasive grass species (Malmstrom et al., 2005).

\section{Concluding Remarks}

In the recent years, a lot of publications which included the new molecular methods have enhanced the development of plant virus ecology. Molecular ecology provides the benefits of improving the traceability in virus populations, establishing the channel for diagnosis of the risk of viral diseases epidemics and magnifying the durable control measures against economically important diseases. The current innovation in the technology makes plant virus ecology a wide research disciple for researchers. For example, spatial and temporal virus spread patterns and which factors contribute in their spread can be understood with the help of remote sensing techniques (Jones, 2014a). Also the diverse and modern molecular tools are very suitable for virus detection, quantification and analysis helpful for data collection regarding the genetic variability of virus populations. The plant virus ecology has entered in modern era in which innovations and advances in technology provide much more effective predictions of epidemic virus breakout on continental or regional levels (Jones, 2014b).

An exciting future is there for the researchers by using the combination of molecular approaches and traditional measures for better understanding the technical points upon genetic variations of particular virus populations. In future, the sudden outbreak of newly emerged viruses in both cultivated and wild plants is worth to research upon because rapidly increasing plants and plant products international trading will results in establishment of different zones of virus populations across different sub continents of the world. Acquiring the ability of prediction about epidemic break outs, require extensive efforts in future. Rapidly increased rate of innovations in the technology is providing a great opportunity to address the plant virus disease threat towards the managed vegetations thus leading to acceleration worldwide accomplishments regarding plant virus ecology which insure that the discipline has an exciting future. 
Acknowledgements and Conflicts. The work was supported by National Natural Science Foundation, China via No. 31301640. The work is a part of research project "Characterization, evolution and biodiversity of begomoviruses". The authors further declare that they have no ethical conflicts and are not interested in any sort of competition.

\section{REFERENCES}

[1] Acosta-Leal, R., Duffy, S., Xiong, Z., Hammond, R. W., Elena, S. F. (2011): Advances in plant virus evolution: translating evolutionary insights into better disease management. Phytopathology 101: 1136-1148.

[2] Adkins, S., Webster, C. G., Kousik, C. S., Webb, S. E., Roberts, P. D., Stansly, P. A., Turechek, W. W. (2011): Ecology and management of whitefly-transmitted viruses of vegetable crops in Florida. - Virus Research 159: 110-114.

[3] Alabi, O. J., Kumar, P. L., Naidu, R. A. (2008): Multiplex PCR for the detection of African cassava mosaic virus and East African cassava mosaic Cameroon virus in cassava. - Journal of Virological Methods 154: 111-120.

[4] Alexander, H. M., Mauck, K. E., Whitfield, A. E., Garret, K. A., Malmstrom, C. M. (2014): Plant virus interactions at the agro-ecological interface. - European Journal of Plant Pathology 138: 529-574.

[5] Anderson, P. K., Cunningham, A. A., Patel, N. G., Morales, F. J., Epstein, P. R., Daszak, P. (2004): Emerging infectious diseases of plants: pathogen pollution, climate change and agro technology drivers. - Trends in Ecology and Evolution 19: 535-544.

[6] Beijerinck, M. W. (1898): Concerning a contagium vivum fluidum as cause of the spot disease of tobacco leaves. In: Johnson J, editor. Phylopathological Classics, No 7. St. Paul: American Phytopathological Society. pp. 33-52.

[7] Bosque-Pérez, N. A., and Eigenbrode S. D. (2011): The influence of virus-induced changes in plants on aphid vectors: insights from luteovirus pathosystems. - Virus Research 159: 201-205.

[8] Boulton, M. I. (2003): Geminiviruses: major threats to world agriculture. - Annals of Applied Biology 142 (2): 143. doi/10.1111/j.1744-7348.2003.tb00239.x

[9] Breitbart, M., Rohwer, F. (2005): Here a virus, there a virus, everywhere the same virus? - Trends in Microbiology 13: 278-284.

[10] Carmo-Sousa, M., Moreno, A., Garzo, E., Fereres, A. (2014): A non-persistently transmitted-virus induces a pull-push strategy in its aphid vector to optimize transmission and spread. - Virus Research 186: 38-46 .

[11] Chellappan, P., Vanitharani, R., Fauquet, C. M. (2005): MicroRNA-binding viral protein interferes with Arabidopsis development. - Proceedings of National Academy of Sciences USA 102: 10381-10386.

[12] Cheng, Y. H., Zheng, Y. X., Tai, C. H., Yen, J. H., Chen, Y. K., Jan, F. J. (2014): Identification, characterisation and detection of a new tospovirus from sweet pepper. - Annals of Applied Biology 164: 107-115.

[13] Cilia, M., Peter, K. A., Bereman, M. S., Howe, K., Fish, T., Smith, D., Gildow, F., MacCoss, M. J., Thannhauser, T. W., Gray, S. M. (2012): Discovery and targeted LCMS/MS of purified polerovirus reveals differences in the virus-host interactome associated with altered aphid transmission. - PLoS ONE 7: e48177. doi:10.1371/journal.pone.0048177.

[14] Cooper, J. I., and Jones, R.A.C. (2006): Wild plants and viruses: under-investigated ecosystems. - Advances in Virus Research 67: 1-47.

[15] Coutts, B. A., Strickland, G. R., Kehoe, M., Severtson, D. L., Jones, R.A.C. (2008): The epidemiology of Wheat streak mosaic virus in Australia: case histories, gradients, mite vectors and alternative hosts. -Australian Journal of Agricultural Research 59: 844-853. 
[16] Culbreath, A. K., and Srinivasan R. (2011): Epidemiology of spotted wilt disease of peanut caused by Tomato spotted wilt virus in the southeastern U.S. - Virus Research 159: 101-109.

[17] Dáder, B., Moreno, A., Viñuela, E., Fereres, A. (2012): Spatio-temporal dynamics of viruses are differentially affected by parasitoids depending on the mode of transmission. Viruses 4: 3069-3089.

[18] Desbiez, C., Joannon, B., Wipf-Scheibel, C., Chandeysson, C., Lecoq, H. (2009): Emergence of new strains of Watermelon mosaic virus in south-eastern France: evidence for limited spread but rapid local population shift. - Virus Research 141: 201-208.

[19] Eigenbrode, S. D, Ding, H., Shiel, P., Berger, P. H. (2002): Volatiles from potato plants infected with potato leafroll virus attract and arrest the virus vector, My zus persicae (Homoptera: Aphididae). - Proceedings of the Royal Society of London Series BBiological Sciences 269: 455-460.

[20] Fargette, D., Konaté, G., Fauquet, C., Mulle, E., Peterschmitt, M., Thresh, J.M. (2006): Molecular ecology and emergence of tropical plant viruses. - Annual Review of Phytopathology 44: 235-260.

[21] Fereres, A., and Moreno, A. (2009): Behavioral aspects influencing plant virus transmission by homopteran insects. - Virus Research 141: 158-168.

[22] Fereres, A., and Raccah, B. (2015): Plant Virus Transmission by Insects. - Els. John Wiley and Sons, Ltd: Chichester. doi:10.1002/9780470015902.a0000760.pub3

[23] Fu, D. Q., Zhu, B. Z., Zhu. H. L., Zhang, H. X., Xie, Y. H., Jiang, W. B., Zhao. X. D., Luo. K. B. (2006): Enhancement of virus-induced gene silencing in tomato by low temperature and low humidity. - Molecular Cells 21(1): 153-60.

[24] Gallitelli, D. (2000): The ecology of Cucumber mosaic virus and sustainable agriculture. - Virus Research 71: 9-21.

[25] Gibbs, A. J., Gibbs, M. A., Ohshima, K., Garcia-Arenal, F. (2008): More about plant virus evolution: past, present and future. - In: E. Domingo, C. Parishand J. Holland (Eds.) Origin and Evolution of Viruses. 2nd edn, (pp. 229-250). London, UK: Academic Press.

[26] Harrington, R., Fleming, R. A., Woiwod, I. P. (2001): Climate change impacts on insect management and conservation in temperate regions: can they be predicted? - Agric For Entomol 3: 233-240.

[27] Hull, R. (2002): Mathews' Plant Virology. 4th edn. London, UK: Academic Press.

[28] Hull, R. (2014): Chapter 15, Ecology, epidemiology, and control of plant viruses. In: Mathews' Plant Virology. 5th edn, (pp. 809-876): Academic Press: London, UK. doi:10.1016/B978-0-12-384871-0.00014-5.

[29] Ingwell, L. L., Eigenbrode, D. D., Bosque-Pérez, N. (2012): Plant viruses alter insect behavior to enhance their spread. - Scientific Reports 2: 578. doi:10.1038/srep00578.

[30] Jiu, M., Zhou, X. P., Tong, L., Xu, J., Yang, X., Wan, F. H., Liu, S. S. (2007): Vectorvirus mutualism accelerates population increase of an invasive whitefly. - PLOS ONE 2: e182. doi:10.1371/journal.pone.0000182.

[31] John, H. (2011): Climate change may bring big ecosystem changes. News Release : Jet Propulsion laboratory. http://www.skepticalscience.com/Big-Ecosystem Changes_NASA.html

[32] Jonathan, D. W., Roossinck, M. J., Richard, S. N., Scheets, K., Michael, W., Palmer, U. M. (2012): Plant Virus Biodiversity and Ecology. - Annual Reviews of Genetics 46: 359369

[33] Jones, R. A. C. (2004): Using epidemiological information to develop effective integrated virus disease management strategies. - Virus Research 100: 5-30.

[34] Jones, R. A. C. (2009): Plant virus emergence and evolution: origins, new encounter scenarios, factors driving emergence, effects of changing world conditions, and prospects for control. - Virus Research 141: 113-130.

[35] Jones, R. A. C. (2014 a): Plant virus ecology and epidemiology: historical perspectives, recent progress and future prospects. - Annals of Applied Biology 164: 320-347. 
[36] Jones, R. A. C. (2014 b): Trends in plant virus epidemiology: opportunities from new or improved technologies. - Virus Research 186: 3-19.

[37] Jones, R. A. C., and Barbetti, M. J. (2012): Influence of climate change on plant disease infections and epidemics caused by viruses and bacteria. - CAB Reviews 7: 1-32. (online publication). http://www.cabi.org/cabreviews.

[38] Jones, R.A.C., and Coutts, B. A. (2015): Spread of introduced viruses to new plants in natural ecosystems and the threat this poses to plant biodiversity. - Molecular plant pathology 16 (6): 541-545.

[39] Jones, R. A. C., Koenig, R., Lesseman, D. E. (1980): Pepino mosaic virus, a new potexvirus from pepino (Solanum muricatum). - Annals of Applied Biology 94: 61-68.

[40] King, A. M. Q., Adams, M. J., Carstens, E. B., Lefkowitz, E. J. (2012): Virus Taxonomy Ninth Report of the International Committee On Taxonomy of Viruses. (1327 p) - San Diego, CA: Elsevier Academic Press.

[41] Kucharek, T., and Purcifull, D. (2001): Aphid-transmitted viruses of cucurbits in Florida. - Plant Pathology Department Circ. 1184. Florida Cooperative Extension Service, Institute of Food and Agricultural Sciences, University of Florida. http://plantpath.ifas.ufl.edu/takextpub/FactSheets/circ1184.pdf.

[42] Lecoq, H., Fabre, P., Joannon, B., Wipf-Scheibel, C., Chandeysson, C., Schoeny, A., Desbiez, C. (2011): Search for factors involved in the rapid shift in Watermelon mosaic virus (WMV) populations in South-eastern France. - Virus Research 159: 115-123.

[43] Ludmerszki, E., Paldi, K., Racz, I., Szigeti, Z., Rudnoy, S.Z. (2014): The promising role of exogenous S- methylmethionine in agriculture, in the case of maize cultivation. Applied Ecology And Environmental Research 12(3): 777-785.

[44] Longdon, B., Blockhourst, M. A., Russell, C. A., Welch, J. J., Jiggins, F.M. (2014): The evolution and genetics of virus host shifts. - PLOS Pathogens 10(11): e1004395.

[45] Makkouk, K. M., and Kumari, S. G. (2009): Epidemiology and integrated management of persistently transmitted aphid-borne viruses of legume and cereal crops in West Asia and North Africa. - Virus Research 141: 209-218.

[46] Malmstrom, C. M., McCullough, A. J, Johnson, H. A, Newton, L. A, Borer, E. T. (2005): Invasive annual grasses indirectly increase virus incidence in California native perennial bunchgrasses. - Oecologia 145: 153-164.

[47] Malmstrom, C. M., Melcher, U., Bosque-Pérez, N. A. (2011): The expanding field of plant virus ecology: historical foundations, knowledge gaps and research directions. Virus Research 159: 84-94.

[48] Mansoor, S., Zafar, Y., Briddon, R.W. (2006): Geminivirus disease complexes: the threat is spreading. - Trends in Plant Sciences 11: 209-212.

[49] Martínez-Ayala, A., Sánchez-Campos, S., Cáceres, F., Aragón-Caballero, L., NavasCastillo, J., Moriones, E. (2014): Characterisation and genetic diversity of pepper leafroll virus, a new bipartite begomovirus infecting pepper, bean and tomato in Peru. - Annals of Applied Biology 164: 62-70.

[50] Márquez, L. M., Redman, R. S., Rodriguez, R. J., Roossinck, M. J. (2007): A virus in a fungus in a plant -three way symbiosis required for thermal tolerance. - Science 315: 513-515.

[51] Maskell, L. C., Raybould, A. F., Cooper, J. I., Edwards, M. L., Gray, A. J. (1999): Effects of turnip mosaic virus and turnip yellow mosaic virus on the survival, growth and reproduction of wild cabbage (Brassica oleracea). -Annals of Applied Biology 135: 401407.

[52] Mauck, K., Bosque-Pérez, N. A., Eigenbrode, S. D, DeMoraes, C. M, Mescher, M. C. (2012): Transmission mechanisms shape pathogen effects on host-vector interactions: evidence from plant viruses. - Functional Ecology 26: 1162-1175.

[53] Mauck, K., DeMoraes, C. M., Mescher, M. C. (2015): Infection of host plants by Cucumber mosaic virus increases the susceptibility of Myzus persicae aphids to the 
parasitoid Aphidius colemani. $\quad-\quad$ Scientific Reports PMC4455285. doi: $10.1038 /$ srep10963

[54] Metz, B., Davidson, O. R., Bosch, P. R., Dave, R., Meyer, L. A. (2007): Climate Change: Mitigation of Climate Change. Contribution of Working Group III to the Fourth Assessment Report of the Intergovernmental Panel on Climate Change. - Cambridge, UK/New York, NY, USA: Cambridge University Press.

[55] Mitchell, C. E, and Power, A. G. (2003): Release of invasive plants from fungal and viral pathogens. - Nature 421: 625-627.

[56] Momol, T., and Pernezny, K. (2006): Florida plant disease management guide. - Tomato. Plant Pathology Department PDMG-V353. Florida Cooperative Extension Service, Institute of Food and Agricultural Sciences, University of Florida. http://edis.ifas.ufl.edu/pg059.

[57] Moreno, A., De-Blas, C., Biurrun, R., Nebreda, M., Palacios, I., Duque, M., Fereres, A. (2004): The incidence and distribution of viruses infecting lettuce, cultivated Brassica and associated natural vegetation in Spain. - Annals of Applied Biology 144: 339-346.

[58] Moreno-Delafuente, A., Garzo, E., Moreno, A., Fereres, A. (2013): A plant virus manipulates the behavior of its whitefly vector to enhance its transmission efficiency and spread. - PLOS ONE 8: 4, e61543.

[59] Morales, F. J. (2006): History and current distribution of begomoviruses in Latin America. - Advances in Virus Research 67: 127-162.

[60] Morales, F. J., Jones, P. G. (2004): The ecology and epidemiology of whitefly-transmitted viruses in Latin America. - Virus Research 100: 57-65.

[61] Mumford, R. A., Jones, R. A. C. (2005): Pepino mosaic virus. - In: AAB Descriptions of Plant Viruses. No. 411.Wellesbourne, UK: Association of Applied Biologists.

[62] Navas-Castillo, J., Fiallo-Olivé, E., Sánchez-Campos, S. (2011): Emerging virus diseases transmitted by whiteflies. - Annual Review of Phytopathology 49: 219-248.

[63] Noman, A., Ali, S., Naheed, F., Ali, Q., Farid, M., Rizwan, M., Irshad, M.K. (2015): Foliar application of ascorbate enhances the physiological and biochemical attributes of maize (Zea mays L.) cultivars under drought stress. - Achieves of Agronomy And Soil Sciences 61: 1659-1672.

[64] Norris, R. F., and Kogan, M. (2005): Ecology of interactions between weeds and arthropods. - Annual Reviews of Entomology 50: 479-503.

[65] Olarte-Castillo, X. A., Fermin, G., Tabima, J., Rojas, Y., Tennant, P. F., Fuchs, M., Sierra, R., Bernal, A. J., Restrepo, S. (2011): Phylogeography and molecular epidemiology of Papaya ringspot virus. - Virus Research 159: 132-140.

[66] Pagan, I., Gonzales-Jara, P., Moreno-Letelier, A., Rodelo-Urrego, M., Pinero, D., GarciaArenal, F. (2012): Effect of biodiversity changes in disease risk: exploring emergence in a plant-virus system. - PLOS Pathogens 7: e1002796. doi:10.1371/journal.ppat.1002796.

[67] Pan, H., Chu, D., Liu, B., Shi, X., Guo, L., Xie, W., Carriere, Y., Li, X., Zhang, Y. (2013): Differential effects of an exotic plant virus on its two closely related vectors. Scientific Reports 3: 2230. doi:10.1038/srep02230.

[68] Parry, M. L., Canziani, O. F., Palutikof, J. P., Van der Linden, P. J., Hanson, C. E. (2007): Climate Change: Impacts, Adaptation and Vulnerability. Contribution of Working Group II to the Fourth Assessment Report of the Intergovernmental Panel for Climate Change. - Cambridge, UK/New York, NY, USA: Cambridge University Press.

[69] Patel, L. B., and Fauquet, M. C. (2011): Ecology of Plant Viruses, with special reference to Giminiviruses. Ecology of plant viruses. - In: Hurst, C., Hoboken, N. J. (eds.) Studies in Viral Ecology (Volume I). (pp. 273-306): John Wiley and Sons, doi: 10.1002/9781118025666.ch11

[70] Prendeville, H. R., Ye, X., Morris, J. T., Pilson, D. (2012): Virus infections in wild plant populations are both frequent and often unapparent. - American Journal of Botany 99: 1033-1042. 
[71] Rajabascar, D., Bosque-Pérez, N. A., Eigenbrode, S. D. (2014): Preference by a virus vector for infected plants is reversed after virus acquisition. - Virus Research 186: 32-37.

[72] Rico, P., Ivars, P., Elena, S.F., Hernández, C. (2006): Insights into the selective pressures restricting Pelargonium flower break virus genome variability: evidence for host adaptation. - Journal of Virology 80: 8124-8132.

[73] Rodelo-Urrego M., Pagán I., González-Jara P., Betancourt M., Moreno-Letelier A., Ayllón M.A., Fraile A.,Piñero D., García-Arenal F. (2013): Landscape heterogeneity shapes host-parasite interactions and results in apparent plant virus codivergence. Molecular Ecology 22: 2325-2340.

[74] Rodríguez-Pardina, P. E., Hanada, K., Laguna, I.G., Zerbini, F.M., Ducasse, D. A. (2011): Molecular characterisation and relative incidence of bean- and soybeaninfecting begomoviruses in northwestern Argentina. - Annals of Applied Biology 158: 69-78.

[75] Rosario, K., Symonds, E. M., Sinigalliano, C., Steward, J., Breitbart, M. (2009): Pepper mild mottle virus as an indicator of fecal pollution. - Applied Environmental Microbiology 75: 7261-7267.

[76] Roossinck, M. J., Saha, P., Wiley, G. B., Quan, J., White, J. D. (2010): Ecogenomics: Using massively parallel pyrosequencing to understand virus ecology. - Molecular Ecology 19(1): 81-88.

[77] Roossinck, M. J. (2012 a): Plant virus metagenomics: biodiversity and ecology. - Annual Review of Genetics 46: 359-369.

[78] Roossinck, M. J. (2012b): Persistent Plant Viruses: Molecular Hitchhikers or Epigenetic Elements. Witzany G, editor. Viruses: Essential Agents of Life. New York: Springer.

[79] Roossinck, M. J. (2013): Plant virus ecology. - PLOS Pathology 9: e1003304. doi:10.137/journal.paat.1003304.

[80] Roossinck, M. J., and Garcia-Arenal, F. (2015): Ecosystem simplification, biodiversity loss and plant emergence. - Current Opinion in Virology 10: 56-62.

[81] Rúa, M. A., Pollina, E. C., Power, A. G., Mitchell, C. E. (2011): The role of viruses in biological invastions: friend or foe? - Current Opinion in Virology 1: 68-72.

[82] Schneider, W. L., and Roossinck, M. J. (2001): Genetic diversity in RNA virus quasispecies is controlled by host-virus interactions. - Journal of Virology 75: 65666571.

[83] Shestra, A., Srinivasan, R., Riley, D. G., Culbreath, A. K. (2012): Direct and indirect effects of thrips-transmitted Tospoviruses on the preference and fitness of its vector, Frankliniella fusca. - Entomologia Experimentalis et Applicata 145: 260-271.

[84] Stafford, C. A., Walker, G. P., Ulman, D. E. (2011): Infection with a plant virus modifies vector feeding behaviour. - Proceedings of the National Academy of Sciences of the United States of America 108: 9350-9355.

[85] Ssweruwagi, P., Rey, M. E. C., Brown, J. K., Legg, J. P. (2004): The cassava mosaic geminiviruses occurring in Uganda following the 1990s epidemic of severe cassava mosaic disease. - Annals of Applied Biology 145: 113-121.

[86] Sserubombwe, W. S., Briddon, R. W., Baguma, Y. K., Ssemakula, G. N., Bull, S. E., Bua, A., Alicai, T., Omongo, C., Otim-Nape, G. W., Stanley, J. (2008): Diversity of begomoviruses associated with mosaic disease of cultivated cassava (Manihot esculenta Crantz) and its wild relative (Manihot glaziovii Mull. Arg.) in Uganda. - Journal of General Virology 89: 1759-1769.

[87] Tahiri, A., Sekkat, A., Bennani, A., Granier, M., Delvare, G., Peterschmitt, M. (2006): Distribution of tomato-infecting begomoviruses and Bemisia tabaci biotypes in Morocco. - Annals of Applied Biology 149: 175-186.

[88] Thapa, V., Melcher, U., Wiley, G. B., Doust, A., Palmer, M. W., Roewe, K., Roe, B. A., Shend, G., Roossinck, M. J., Wang, Y. M., Kamath, N. (2012): Detection of members of the Secoviridae in the Tall Grass Prairie Preserve, Osage County, Oklahoma, USA. Virus Research 167: 34-42. 
[89] Thresh, J. M. (2003): Control of plant virus diseases in Sub-Saharan Africa: the possibility and feasibility of an integrated approach. - African crop science journal 11(3): 199-223.

[90] Thresh, J. M. (2006a): Plant virus epidemiology. - Advances in Virus Research 67: 1-544.

[91] Thresh, J. M. (2006b): Control of tropical plant virus diseases. - Advances in Virus Research 67: 245-295.

[92] Thresh, J. M. (2006c): Plant virus epidemiology: the concept of host genetic vulnerability. - Advances in Virus Research 67: 89-125.

[93] Thresh, J. M., Fargette, D. (2003): The epidemiology of African plant viruses: basic principles and concepts. - In: Hughes, J.d'.A., Odu, B.O. (eds) Plant Virology in SubSaharan Africa, pp. 61-111. Ibadan, Nigeria: International Institute for Tropical Agriculture.

[94] Traore, O., Pinel-Galzi, A., Sorho, F., Sarra, S., Rakotomalala, M., Sangu, E., Kaneya, Z., Sere, Y., Konate, G., Fargette, D. (2009): A reassessment of the epidemiology of Rice yellow mottle virus following recent advances in field and molecular studies. - Virus Research 141: 258-267.

[95] Trebicki, P., Harding, R. M., Rodoni, B., Baxter, G., Powell, K. S. (2010): Vectors and alternative hosts of tobacco yellow dwarf virus in southeastern Australia. - Annals of Applied Biology 157: 13-24.

[96] Tsai , W. S., Shih, S. L., Venkatesan, S. G., Aquino, M. U., Green, S. K., Kenyon, L., Jan, F. J. (2011): Distribution and genetic diversity of begomoviruses infecting tomato and pepper plants in the Philippines. - Annals of Applied Biology 158: 275-287.

[97] Tsai, W. S., Shih, S. L., Rauf, A., Safitri, R., Hidayati, N., Huyen, B. T. T., Kenyon, L. (2013): Genetic diversity of legume yellow mosaic begomoviruses in Indonesia and Vietnam. - Annals of Applied Biology 163(3): 367-377. doi: 10.1111/aab.12063.

[98] Tugume, A. K., Amayo, R., Weinheimer, I., Mukasa, S. B., Rubaihayo, P. R., Valkonen, J. P. T. (2013): Genetic variability and evolutionary implications of RNA silencing suppressor genes in RNA1 of Sweet potato chlorotic stunt virus isolates infecting sweetpotato and related wild species. - PLOS ONE 8: e81479.

[99] Vanitharani, R., Chellappan, P., Fauquet, C. M. (2005): Geminiviruses and RNA silencing. - Trends in Plant Sciences 10: 144-151.

[100] Varma, A., and Malathi, V. G. (2003): Emerging geminivirus problems: a serious threat to crop production. - Annals of Applied Biology 142: 145-164.

[101] Vincent, S. J., Coutts, B. A., Jones, R. A. C. (2014): Effects of introduced and indigenous viruses on native plants: exploring their disease causing potential at the agro-ecological interface. - PLoS ONE 9: e91224. doi:10.137/journal.pone.0091224.

[102] Van der Vlugt, R. A. A., Stijger, C. C. M. M., Verhoeven, J. Th. J., Lesseman, D. E. (2000): First report of Pepino mosaic virus on tomato. - Plant Disease 84: 103.

[103] Wang, J., Bing, X. L., Li, M., Ye, G. Y., Liu, S. S. (2012): Infection of tobacco plants by a begomovirus improves nutritional assimilation by a whitefly. - Entomologia Experimentalis et Applicata 144: 191-201.

[104] Westwood, J. H., Simon, C. G., Zhiyou, D., Alex, M. M., Damar, T. A., Trisna, T., Vijitra, L. I., Methew, G. L., John, T. R., Glen, P., Alison, G. S., John. P. C. (2013): A trio of Viral proteins tunes Aphid-Plant Interactions in Arabidopsis Thaliana. - PLoS ONE doi.org/10.1371/journal.pone.0083066

[105] Wilson, C. R. (2014): Applied Plant Virology. Wallingford, UK: CABI Press.

[106] Woolhouse, M. E, Taylor, L. H., Haydon, D. T. (2001): Population biology of multi host pathogens. - Science 292: 1109-1112.

[107] Zhang, T., Luan, J. B., Qi, J. F., Huang, C. J., Li, M., Zhou, X. P., Liu, S. S. (2012): Begomovirus-whitefly mutualism is achieved through repression of plant defenses by a virus pathogenicity factor. - Molecular Ecology 21: 1294-1304.

[108] Zhou, X. (2013): Advances in understanding begomovirus satellites. - Annual Review of Phytopathology 51: 357-381. 